\title{
Characterization of genetic diversity of native 'Ancho' chili populations of Mexico using microsatellite markers
}

Rocío Toledo-Aguilar ${ }^{1}$, Higinio López-Sánchez ${ }^{2 *}$, Amalio Santacruz-Varela ${ }^{1}$, Ernestina Valadez-Moctezuma ${ }^{3}$, Pedro A. López², Víctor H. Aguilar-Rincón' ${ }^{1}$, Víctor A. González-Hernández ${ }^{1}$, and Humberto Vaquera-Huerta ${ }^{1}$

\section{ABSTRACT}

‘Ancho' type chilis (Capsicum annuum L. var. annuum) are an important ingredient in the traditional cuisine of Mexico and so are in high demand. It includes six native sub-types with morphological and fruit color differences. However, the genetic diversity of the set of these subtypes has not been determined. The objective of this study was to characterize the genetic diversity of native Mexican ancho chili populations using microsatellites and to determine the relationship among these populations. Twenty-four microsatellite loci were used to analyze 38 native populations of 'Ancho' chilis collected in seven states of Mexico; three populations different from the ancho type ('Piquin', 'Guajillo', and 'Chilaca') and three hybrids (Capulin, Abedul, and green pepper) were included as controls. The number of alleles per locus, number and percentage of polymorphic loci, polymorphic information content (PIC), expected heterozygosity, and Wright $\mathrm{F}$ statistics were obtained. Moreover, an analysis of principal components and a cluster analysis were carried out. We detected 220 alleles, with an average of 9.2 alleles per locus; PIC varied between 0.07 and 1 , and expected heterozygosity was between 0.36 and 0.59 . Also we identified 59 unique alleles and eight alleles common to all of the populations. The F statistics revealed broad genetic differentiation among populations. Both the analysis of principal components and the cluster analysis were able to separate the populations by origin (southern, central, and northern Mexico). The broad genetic diversity detected in the native ancho chili populations of Mexico was found in greater proportion within the populations than between populations.

Key words: Capsicum annuum, genetic characterization, microsatellites, multiple PCR, polymorphism, variability.

${ }^{1}$ Colegio de Postgraduados, Campus Montecillo, km 36,5 Carretera México-Texcoco, Montecillo, Texcoco 56230, Estado de México, México.

${ }^{2}$ Colegio de Postgraduados, Campus Puebla, km 125,5 Carretera Federal México-Puebla, Santiago Momoxpan, San Pedro Cholula 72760, Puebla, México.

*Corresponding author (higiniols@ colpos.mx).

${ }^{3}$ Universidad Autónoma Chapingo, km 38,5 Carretera MéxicoTexcoco, Chapingo 56230, Estado de México, México.

Received: 3 February 2015

Accepted: 21 August 2015.

doi:10.4067/S0718-58392016000100003

\section{INTRODUCTION}

Due to the great existing genetic diversity in chili, to the scattering and domestication process in different countries (HernándezVerdugo et al., 1999), in different ecological environments and for multiple uses, currently there is a lot of morphotypes and subtypes of chili. An example is the case of Edward Long, who in 1774 described 15 types of chili of Capsicum chinense Jacq. he found in the Caribbean, being the most common 'Goat', 'Bonnett', 'Bird', 'Olive', 'Hen', 'Barbary', 'Finger' and 'Cherry' (Long, 2009). Cases like the one mentioned above can cause confusion since it is likely that the same type of chili can receive different names.

In Mexico, chilis of the 'Ancho' type are the second most important of the genus Capsicum, because of both the economic resources they generate (SIAP-SAGARPA, 2012) and their use in the preparation of traditional dishes, the reason it is highly demanded. Ancho chilis are some of the many morphotypes of the species Capsicum annuum L. var. апnиит found in Mexico. Six sub-types are known as ancho-type chilis. 'Mulato', which measure approximately $18 \times 8 \mathrm{~cm}$, is brown when ripe and have triangular shape. 'Ancho' chilis are also triangular measuring 12 $\times 6.5 \mathrm{~cm}$ approximately, and are red when ripe. The sub-type of 'Cristalino' chilis measure $12 \times 6 \mathrm{~cm}$, are triangular and during its process of maturation goes from lime green to yellow, to orange and finally to red. 'Huacle' chilis measure $10 \times 8 \mathrm{~cm}$ approximately, are black when ripe and have a trapezoidal shape. This sub-type is grown only in the state of Oaxaca. 'Miahuateco' chilis measure 13 $\times 3 \mathrm{~cm}$ and ripen to dark brown; they are native only to the state of Puebla. "Dulce", or sweet, chilis belong to the state of Yucatán; they measure $7 \times 7 \mathrm{~cm}$, are red when ripe and are kidney shaped. This set of ancho-type chilis can be found in at least nine states of Mexico (Aguilar et al., 2010). Despite their importance, there are no studies on the genetic diversity of this set of ancho chilis native to Mexico. This knowledge would enable the development of schemes for conservation, breeding and use of this resource.

Molecular markers are a reliable tool for quantification of genetic diversity since they are not affected by the environment and are highly reproducible (Laurentin, 2009). The microsatellite markers, or Simple Sequence Repeats (SSR) markers, have boomed in recent years; they are highly variable, are co-dominant, found throughout the genome and are highly polymorphic (Varshney et al., 2005). They can better differentiate related materials (Pejic et al., 1998) and they are thus ideal for detecting differences within and among species, as well as for determining paternity (Farooq and Azam, 2002). For these reasons, SSR markers have been used to map the genomes of a large number of species, to quantify 
genetic diversity, to assist selection through markers, and to differentiate varieties and genetic fingerprint (Varshney et al., 2005). Thousands of microsatellite markers have been developed to map the genome of the genus Capsicum (Lee et al., 2004; Minamiyama et al., 2006; Yi et al., 2006; Nagy et al., 2007; Portis et al., 2007; Wu et al., 2009; Mimura et al., 2012; Sugita et al., 2013; Ahn et al., 2014). Identification of these SSR markers has also served for quantification of genetic diversity in $C$. annuum (Hanáček et al., 2009), $C$. frutescens L. (Rodrigues and Tam, 2010), C. chinense (Moses et al., 2014) and for interspecific analyses (Stágel et al., 2009; Ince et al., 2010; Yumnam et al., 2012; Rai et al., 2013). All of these studies found that the genus Capsicum is highly polymorphic, especially in native populations. Studies on different chili species have confirmed the usefulness of the SSR markers in differentiating Capsicum genetic materials.

In Mexico, also, studies with microsatellites have been conducted to analyzed genetic diversity of chili types. González-Jara et al. (2011) tested 10 SSR in 27 populations of 'chiltepin' ( $C$. annuum L. var. glabriusculum (Dunal) Heiser \& Pickersgill), and Pacheco-Olvera et al. (2012) used 14 SSR loci to compare 22 populations of $C$. аnпиum with different genetic base. Also, Contreras et al. (2011) examined genetic diversity of 'Mulato' chili (C. annuum var. annuиm) populations from Puebla with 19 SSR markers. In recent years, progress has been observed in the study of genetic diversity of the species of the genus Capsicum with the use of microsatellites. However, there are still many types of chilis to be examined, especially in Mexico, which is considered the center of origin and genetic diversity of $C$. annuum (Pickersgill, 2007). For this reason, the objective of this study was to characterize the genetic diversity of a set of native 'Ancho' type chili populations using SSR molecular markers and to identify the genetic relationships among the studied populations.

\section{MATERIALS AND METHODS}

\section{Plant material and DNA extraction}

We studied 38 native populations (core collection) of ancho chili: eleven of 'Mulato' collected in Mexican states of Guanajuato $\left(19^{\circ} 54^{\prime}\right.$ to $21^{\circ} 50^{\prime} \mathrm{N}$ and $99^{\circ} 41^{\prime}$ to $102^{\circ} 04^{\prime} \mathrm{W}$ ), Zacatecas $\left(21^{\circ} 12^{\prime}\right.$ to $25^{\circ} 13^{\prime} \mathrm{N}$ and $101^{\circ} 11^{\prime}$ to $104^{\circ} 27^{\prime} \mathrm{W}$ ), Durango $\left(22^{\circ} 24^{\prime}\right.$ to $26^{\circ} 58^{\prime} \mathrm{N}$ and $102^{\circ} 52^{\prime}$ to $106^{\circ} 39^{\prime} \mathrm{W}$ ), San Luis Potosí $\left(21^{\circ} 08^{\prime}\right.$ to $24^{\circ} 93^{\prime} \mathrm{N}$ and $98^{\circ} 18^{\prime}$ to $102^{\circ} 16^{\prime}$ $\mathrm{W})$ and Puebla $\left(17^{\circ} 52^{\prime}\right.$ to $20^{\circ} 35^{\prime} \mathrm{N}$ and $96^{\circ} 44^{\prime}$ to $\left.99^{\circ} 00^{\prime} \mathrm{W}\right)$, 17 of ancho collected in Guanajuato, Zacatecas, Durango and San Luis Potosí, four of 'Cristalino' collected in Guanajuato and Durango, two of 'Miahuateco' collected in Puebla, one of 'Huacle' collected in Oaxaca $\left(15^{\circ} 38^{\prime}\right.$ to $18^{\circ} 42^{\prime} \mathrm{N}$ and $96^{\circ} 41^{\prime}$ to $98^{\circ} 36^{\prime} \mathrm{W}$ ), one of 'Chilaca' collected in Oaxaca, and three sweet collected in Yucatán (19³4' to $21^{\circ} 36^{\prime} \mathrm{N}$ and $87^{\circ} 33^{\prime}$ to $90^{\circ} 32^{\prime} \mathrm{W}$ ). In order to establish phylogenetic relationships a population of 'Piquin' chili (Capsicum anпиит L. var. glabriusculum (Dunal) Heiser \& Pickersgill) was included to be used as an external group, since it is considered ancestor of the species $C$. annuum L. (Votava et al., 2002; Aguilar-Meléndez et al., 2009). Also a collection of 'Guajillo' and one of 'Chilaca' were included as types different from anchos, and the commercial hybrids Capulin ('Ancho' 'Mulato'), Abedul (red ancho) (HM.CLAUSE, Davis, California, USA), and a commercial hybrid of green pepper ('Happy Flower'). The green pepper was included to determine whether it is genetically close to the sweet peppers of Yucatán. Total genomic DNA was extracted from 10 seedlings per population $15 \mathrm{~d}$ after sowing using an extraction robot KingFisher Flex (Thermo Fisher Scientific, Waltham, Massachusetts, USA) and the ChargeSwitch gDNA Plant Kit (Invitrogen Corporation, Carlsbad, California, USA).

\section{Microsatellite loci amplification and fragment analysis}

Twenty-four microsatellite loci were selected from the study of Lee et al. (2004) and Contreras et al. (2011) and marked with fluorescent labels 6-FAM or HEX (Applied Biosystems, Foster City, California, USA) at the 5' tip (Table 1) to enable detection with capillary electrophoresis. To a final volume of $25 \mu \mathrm{L}, 10 \mathrm{pM}$ of each primer, $0.2 \mathrm{mM}$ nucleotides, $1 \mathrm{X}$ buffer, $3 \mathrm{mM} \mathrm{MgCl}$, one DNA Taq polymerase unit and 40 ng DNA template was added. In the thermocycler GeneAmp PCR System 9700 (Applied Biosystems), multiple and single PCR fragments were amplified; fragments were obtained by denaturalization, initially for $4 \mathrm{~min}$ at $94{ }^{\circ} \mathrm{C}$, then 30 or 35 cycles of $1 \mathrm{~min}$ at $94{ }^{\circ} \mathrm{C}, 1 \mathrm{~min}$ at $53-64{ }^{\circ} \mathrm{C}$ and 2 min at 72 ${ }^{\circ} \mathrm{C}$. The final extension was $12 \mathrm{~min}$ at $72^{\circ} \mathrm{C}$. Information about aligning temperatures and the cycles used for eight multiple PCR groups, as well as two single amplifications are shown in Table 1 . The PCR products were separated by capillary electrophoresis in the ABI3130 sequencer (Applied Biosystems). In a reaction mixture, $2 \mu \mathrm{L}$ PCR product and $0.25 \mu \mathrm{L}$ of GeneScan -500 LIZ Size Standard (molecular weight marker, Applied Biosystems) and $7.75 \mu \mathrm{L}$ of $\mathrm{Hi}-$ Di formamide (Applied Biosystems) were added. During the runs, a voltage of $1500 \mathrm{~V}$ was maintained at $60{ }^{\circ} \mathrm{C}$ for $15 \mathrm{~min}$; injection time was 16 or $32 \mathrm{~s}$. As support for the separation, a G5 filter set and the polymer POP-7 were used, and for detection of the fluorophores FAM, HEX and size standard LIZ, the DS-33 Dye Primer Matrix Standard Set were used. The runs obtained were analyzed with the software GeneMapper version 4.0 (Applied Biosystems, 2005 ) for the detection of alleles and their sizes (base pairs).

\section{Statistical analysis}

Based on the register of the different alleles found in 44 materials, allele frequencies by group (more than two population of the same chili sub-type) and single (a single population of a sub-type under study) were obtained using the software POPGENE version 1.31 (Yeh et al., 1999). The number of alleles per locus, number and percentage of polymorphic loci, polymorphic information content 
Table 1. Description of microsatellite loci, multiple and single PCR alignment conditions, polymorphic information content (PIC) of the loci, and number of alleles in the molecular characterization of native ancho chili populations of Mexico.

\begin{tabular}{|c|c|c|c|c|c|c|c|c|}
\hline Group & Locus & Repeated unit & Initiators $\left(5^{\prime}-3^{\prime} / 3^{\prime}-5^{\prime}\right)$ & $\mathrm{FL}^{\dagger}$ & $\mathrm{FS}(\mathrm{pb})$ & $\begin{array}{c}\mathrm{Tm} \\
\left({ }^{\circ} \mathrm{C}\right) \text {-cycles }\end{array}$ & PIC & NA \\
\hline \multirow[t]{2}{*}{1} & Hpms1-106 & $(\mathrm{AAAAAT})_{4}$ & tccaaactacaagcetgcctaacc/ttttgcattattgagtcccacagc & HEX & $150-163$ & $53-35$ & 0.14 & 6 \\
\hline & Hpms 2-2 & $(\mathrm{GT})_{9}$ & gcaaggatgcttagttgggtgtc/tcccaaaattacettgcag & 6-FAM & $136-151$ & & 0.90 & 8 \\
\hline \multirow[t]{4}{*}{2} & AF039662 & $\mathrm{T}_{26 \mathrm{IMP}}{ }^{\dagger \dagger}$ & ccccctcgtctctctttattt/ttgcaaatcttttgtcaattttt & 6-FAM & $111-130$ & $56-30$ & 0.78 & 8 \\
\hline & CM0005 & $(\mathrm{CCA})_{8}$ & catgaccaccatgaggata/gatagccacgagcatagtatt & 6-FAM & $153-160$ & & 0.07 & 5 \\
\hline & Hpms1-1 & $(\mathrm{CA})_{12}(\mathrm{TA})_{4}$ & tcaacccaatattaaggtcacttcc/ccaggcggggattgtagatg & 6-FAM & $258-287$ & & 0.91 & 12 \\
\hline & Hpms1-274 & $(\mathrm{GTT})_{7}$ & tcccagacccctcgtgatag/tcctgctccttccacaactg & HEX & $164-179$ & & 0.90 & 7 \\
\hline \multirow[t]{4}{*}{3} & Hpms1-62 & $(\mathrm{TG})_{23}(\mathrm{AG})_{9}$ & catgaggtctcgcatgatttcac/ggagaaggaccatgtactgcagag & 6-FAM & $185-210$ & $54-30$ & 0.48 & 9 \\
\hline & $A F 244121$ & $(\mathrm{TTG})_{5 I M P}(\mathrm{AT})_{6 I M P}(\mathrm{GT})_{3 \mathrm{IMP}}$ & tacctcctcgccaatccttctg/ttgaaagttctttccatgacaacc & 6-FAM & $221-248$ & & 0.93 & 12 \\
\hline & Hpms1-148 & $(\mathrm{GA})_{14}$ & ggcggagaagaactagacgattagc/ccacccaatccacatagacg & HEX & 183-195 & & 1.00 & 7 \\
\hline & HpmsCaSIG19 & $(\mathrm{CT})_{6}(\mathrm{AT})_{8}(\mathrm{GTAT})_{5}$ & catgaatttcgtcttgaaggtccc/aagggtgtatcgtacgcagcctta & HEX & $217-229$ & & 0.19 & 10 \\
\hline \multirow[t]{2}{*}{4} & CAN010950 & $(\mathrm{TA})_{9}$ & gatttggtggcagaagaattgg/tgcactttcgaagcaaacaaacc & 6-FAM & $245-276$ & $56-30$ & 0.14 & 5 \\
\hline & Hpms2-13 & $(\mathrm{AC})_{12}(\mathrm{AT})_{4}$ & tcacctcataagggcttatcaatc/tccttaaccttacgaaaccttgg & HEX & $219-259$ & & 0.28 & 11 \\
\hline \multirow[t]{3}{*}{5} & Hpms1-5 & $(\mathrm{AT})_{11}(\mathrm{GT})_{17}$ & ccaaacgaaccgatgaacactc/gacaatgttgaaaaaggtggaagac & 6-FAM & $297-318$ & $62.5-30$ & 0.21 & 13 \\
\hline & Hpms1-168 & $(\mathrm{TA})_{17}(\mathrm{GA})_{12}$ & gccccgatcaatgaatttcaac/tgattttgggtggagagaaaacc & HEX & $159-178$ & & 0.82 & 10 \\
\hline & Hpms1-172 & $(\mathrm{GA})_{15}$ & gggtttgcatgatctaagcatttt/cgctggaatgcattgtcaaaga & HEX & $336-346$ & & 0.83 & 10 \\
\hline \multirow[t]{3}{*}{6} & Hpms1-214 & (GTTT) & tgcgagtaccgagttctttctag/ggcagtcctgggacaactcg & 6-FAM & $81-107$ & $59.5-30$ & 0.77 & 14 \\
\hline & HpmsAT2-14 & $(\mathrm{AAT})_{16}$ & tttagggtttccaactcttcttcc/ctaaccccaccaagcaaaacac & 6-FAM & 176 & & 0.00 & 1 \\
\hline & Hpms1-6 & $(\mathrm{AT})_{2}(\mathrm{GT})_{4}(\mathrm{AT})_{8}(\mathrm{GT})_{13}$ & tccataacttcacccatgagtatga/gcaacacccacattccettctc & HEX & $180-200$ & & 0.10 & 10 \\
\hline \multirow[t]{2}{*}{7} & Hpms1-173 & $(\mathrm{GA})_{16}(\mathrm{TG})_{2}$ & tgctgggaaagatctcaaaagg/atcaaggaagcaaaccaatgc & HEX & $157-169$ & $53-30$ & 0.09 & 8 \\
\hline & Hpms1-143 & $(\mathrm{AG})_{12}$ & aatgctgagctggcaaggaaag/tgaaggcagtaggtggggagtg & 6-FAM & $216-239$ & & 0.21 & 12 \\
\hline \multirow[t]{4}{*}{8} & Hpms1-111 & $(\mathrm{AAT})_{11}$ & aagcttatccctttcaaatataa/atatctcacgtattgcggattctt & HEX & $145-166$ & $56-30$ & 0.40 & 9 \\
\hline & Hpms $2-24$ & $(\mathrm{CT})_{17}(\mathrm{CA})_{5} \mathrm{~A}_{21}$ & tcgtattggettgtgatttaccg/ttgaatcgaataccegcaggag & 6-FAM & $183-204$ & & 0.24 & 12 \\
\hline & Hpms2-21 & $(\mathrm{AT})_{11}(\mathrm{AC})_{9}(\mathrm{ATAC})_{10}$ & $\mathrm{ttt}$ & HEX & $264-305$ & $64-30$ & 0.45 & 16 \\
\hline & CAN130829 & $\mathrm{T}_{16}$ & gctaattacttgctccgttttg/aatgggggagtttgttttgg & 6-FAM & $182-186$ & $64-30$ & 0.99 & 5 \\
\hline
\end{tabular}

${ }^{\dagger}$ FL: Fluorescent label; FS: fragment size; Tm: alignment temperature; NA: number of alleles; ††IMP: imperfect repetition.

(PIC) (Nei et al., 1983), expected heterozygosity (He) (Nei, 1973), and Wright F statistics (Wright, 1965) were also recorded. With the matrix of correlations generated by allele frequencies, an analysis of principal components (APC) was performed with the SAS software version 9.3 (SAS Institute, Cary, North Carolina, USA), and a cluster analysis using Rogers genetic distances modified by Wright (1978) and the Neighbor Joining cluster method (Saitou and Nei, 1987) in the software NTSYS version 2.21 (Rohlf, 2009).

\section{RESULTS AND DISCUSSION}

\section{Population genetic diversity}

In the 44 genetic materials studied, 220 alleles were detected, with an average of 9.2 alleles per locus; 23 loci were polymorphic and only the locus Hpms AT2-14 was not. The loci Hpms2-21, Hpms1-214, and Hpms1-5 were those that exhibited the most polymorphism for native Mexican ancho chilis, with 16, 14 and 13 alleles found. The allelic information showed that the 'Mulato' and ancho types had 21 and 20 polymorphic loci on average (Table 2), while 'Piquin', commercial green pepper and 'Cristalino' chilis had 18 polymorphic loci. The genetic diversity in native populations of ancho chilis analyzed with microsatellites is broad. In similar studies, such as Contreras et al. (2011), fewer alleles were found (105 for 19 loci in populations of
'Mulato' chilis from Puebla, Mexico), likely because they studied only one sub-type of ancho chili. In studies among species of the genus Capsicum, a larger number of alleles has been found. For example, Ibiza et al. (2012) found an average of 14.5 alleles with 10 microsatellites for a total of 270 populations. In wild chilis (C. апnиит var. glabriusculum), González-Jara et al. (2011) found greater variation, with 27 alleles per locus. In contrast, with commercial varieties the number of alleles is very low (Kwon et al., 2005), because of their narrow genetic base. Likewise, Aktas et al. (2009) found very few alleles in cultivars introduced into Turkey.

Expected heterozygosity was within a range of 0.36 to 0.59. 'Mulato' and ancho chilis were those that showed more likelihood of finding heterozygotes in their populations, while the lowest values were found in the hybrid chilis $(0.36$ and 0.38$)$ and the green pepper variety (0.37), and thus the greatest homozygosis occurs in these hybrids. In general, smaller genetic diversity have been reported for native and wild chili populations than for other crops such as maize (Zea mays L.), whose genetic diversity is far greater ( $\mathrm{Sa}$ et al., 2010; Warburton et al., 2011). Pacheco-Olvera et al. (2012) reported expected heterozygosity in C. аппиит of 0.47 for wild populations and 0.42 for native Mexican chili populations. Moreover, Nicolaï et al. (2013) found heterozygosity of 0.59 in native $C$. аппиит populations and 0.78 in C. annuum var. glabriusculum.

In Mexican ancho chili populations, exclusive alleles were also found in 17 of 24 loci analyzed, $30 \%$ of the total 
Table 2. Allelic information of ancho chilis and their controls for $\mathbf{2 4}$ microsatellite loci.

\begin{tabular}{|c|c|c|c|c|c|c|c|c|c|}
\hline & Chili type & Num. Pop & ANPL & PPL (\%) & NA & ANA & $\mathrm{SD}$ & $\mathrm{He}$ & SD \\
\hline \multirow[t]{5}{*}{ Groups } & 'Mulato' & 11 & 21 & 87.5 & 151 & 6.3 & 2.8 & 0.59 & 0.22 \\
\hline & 'Ancho' & 17 & 20 & 83.3 & 153 & 6.4 & 3.1 & 0.54 & 0.24 \\
\hline & 'Cristalino' & 4 & 18 & 75.0 & 92 & 3.8 & 1.9 & 0.45 & 0.27 \\
\hline & 'Miahuateco' & 2 & 19 & 79.2 & 70 & 2.9 & 1.6 & 0.43 & 0.24 \\
\hline & Sweet & 3 & 19 & 79.2 & 71 & 3.0 & 1.3 & 0.48 & 0.21 \\
\hline \multirow[t]{7}{*}{ Individuals } & 'Huacle' & 1 & 19 & 79.2 & 63 & 2.6 & 1.5 & 0.45 & 0.26 \\
\hline & 'Chilaca' & 1 & 21 & 87.5 & 69 & 2.9 & 1.3 & 0.48 & 0.24 \\
\hline & ‘Piquin’ & 1 & 18 & 75.0 & 57 & 2.5 & 1.3 & 0.40 & 0.25 \\
\hline & ‘Guajillo’' & 1 & 22 & 91.7 & 70 & 3.0 & 1.3 & 0.48 & 0.21 \\
\hline & Green pepper & 1 & 18 & 75.0 & 56 & 2.3 & 1.3 & 0.37 & 0.26 \\
\hline & Hybrid 'Mulato' & 1 & 18 & 75.0 & 52 & 2.2 & 1.0 & 0.36 & 0.25 \\
\hline & Hybrid 'Ancho' & 1 & 19 & 79.2 & 53 & 2.2 & 0.9 & 0.38 & 0.23 \\
\hline
\end{tabular}

Num. Pop: Number of populations; ANPL: average number of polymorphic loci; PPL: percent polymorphic loci; NA: number of alleles; ANA: average number of alleles; SD: standard deviation; He: expected heterozygosity.

number of alleles found (Table 3). The populations of sweet peppers of Yucatán were those that had the highest number of these alleles. 'Mulato' chilis also had a high number of exclusive alleles in these populations, mainly those chilis collected in Puebla, with seven exclusive alleles for five populations. In contrast, the populations of 'Guajillo' and the 'Cristalino' chilis in this study had no exclusive alleles; it is possible that with a larger number of studied populations exclusive alleles might be found since there are many native populations of these chilis in Mexico. Furthermore, in the populations of ancho chili and their controls, there were eight alleles that were common to all the accessions: C-184 pb, D-185 pb (CAN130829), D-171 pb (Hpms 1-168), A-111 pb (AF039662), E-176 pb (Hpms1-274), E-148 pb (Hpms22), H-196 pb (Hpms1-6), and C-260 pb (CAN010950).

The broad genetic diversity in ancho chili populations may be explained by cross-pollination degree of species; levels of up to $90 \%$ have been reported (Pickersgill, 1997; Djian-Caporalino et al., 2006). This is the reason for the abundance of polymorphism. Exclusive alleles were also

Table 3. Exclusive alleles in ancho-type chilis and controls.

\begin{tabular}{|c|c|c|c|c|c|}
\hline Locus & Allele - size (pb) & Group/Ind & Locus & Allele - size (pb) & Group/Ind \\
\hline Hpms1-106 & $\begin{array}{l}A-150 \\
B-151 \\
C-156 \\
E-160\end{array}$ & $\begin{array}{c}\text { Sweet } \\
\text { Sweet } \\
\text { 'Mulato' } \\
\text { Sweet }\end{array}$ & Hpms1-173 & $\begin{array}{l}A-157 \\
B-159 \\
G-168 \\
H-169\end{array}$ & $\begin{array}{l}\text { 'Piquin' } \\
\text { Sweet } \\
\text { Ancho } \\
\text { Ancho }\end{array}$ \\
\hline HpmsCASIG 19 & $\begin{array}{l}\text { A - } 217 \\
\text { I - } 227\end{array}$ & $\begin{array}{l}\text { 'Ancho' } \\
\text { 'Piquin' }\end{array}$ & CM005 & $\begin{array}{l}C-157 \\
E-160\end{array}$ & $\begin{array}{c}\text { Sweet } \\
\text { Green Pepper }\end{array}$ \\
\hline Hpms 1-1 & $\begin{array}{l}C-260 \\
D-269 \\
F-273 \\
G-279 \\
I-281 \\
L-287\end{array}$ & $\begin{array}{l}\text { 'Mulato' } \\
\text { 'Piquin' } \\
\text { 'Mulato' } \\
\text { Sweet } \\
\text { Sweet } \\
\text { 'Piquin' }\end{array}$ & Hpms2-13 & $\begin{array}{l}\text { A - } 221 \\
\text { F - } 228 \\
\text { G - } 229 \\
\text { I - } 233 \\
\text { J - } 234 \\
\text { K - } 259\end{array}$ & $\begin{array}{c}\text { Sweet } \\
\text { 'Mulato', } \\
\text { 'Mulato' } \\
\text { Ancho } \\
\text { 'Mulato' } \\
\text { Sweet }\end{array}$ \\
\hline CAN010950 & $\begin{array}{l}A-245 \\
D-266 \\
E-276\end{array}$ & $\begin{array}{l}\text { 'Ancho' } \\
\text { 'Chilaca', } \\
\text { 'Ancho' }\end{array}$ & Hpms1-5 & $\begin{array}{l}A-297 \\
B-301 \\
L-317\end{array}$ & $\begin{array}{l}\text { 'Miahuateco' } \\
\text { 'Miahuateco' } \\
\text { Green Pepper }\end{array}$ \\
\hline Hpms1-6 & $\begin{array}{l}\text { A- } 180 \\
\text { B - } 183 \\
\text { E- } 186 \\
\text { I - } 198 \\
\text { J - } 200\end{array}$ & $\begin{array}{l}\text { 'Mulato' } \\
\text { Sweet } \\
\text { Sweet } \\
\text { Sweet } \\
\text { 'Mulato' }\end{array}$ & Hpms2-24 & $\begin{array}{l}\text { E - } 187 \\
F-195 \\
G-199 \\
I-201 \\
L-204\end{array}$ & $\begin{array}{l}\text { 'Mulato' } \\
\text { Ancho } \\
\text { 'Chilaca' } \\
\text { Ancho } \\
\text { 'Mulato' }\end{array}$ \\
\hline Hpms 1-143 & $\begin{array}{l}\text { A - } 216 \\
B-218 \\
C-219 \\
I-230 \\
J-233 \\
K-234 \\
L-239\end{array}$ & $\begin{array}{c}\text { Green Pepper } \\
\text { 'Mulato' } \\
\text { Sweet } \\
\text { Green Pepper } \\
\text { 'Mulato' } \\
\text { 'Mulato' } \\
\text { Sweet }\end{array}$ & $\begin{array}{l}\text { Hpms1-111 } \\
\text { Hpms1-168 }\end{array}$ & $\begin{array}{l}A-145 \\
G-160 \\
H-164 \\
I-166 \\
A-159 \\
B-163 \\
I-177\end{array}$ & $\begin{array}{c}\text { Green Pepper } \\
\text { 'Mulato' } \\
\text { 'Huacle' } \\
\text { 'Huacle' } \\
\text { 'Chilaca' } \\
\text { 'Chilaca' } \\
\text { Ancho }\end{array}$ \\
\hline Hpms2-2 & B - 137 & 'Chilaca' & Hpms2-21 & C - 283 & Green Pepper \\
\hline Hpms 1-274 & B - 167 & 'Chilaca' & & $\mathrm{G}-287$ & 'Mulato' \\
\hline Hpms 1-148 & C - 190 & 'Piquin' & & & \\
\hline
\end{tabular}

Ind: Individuals (A single population in the evaluation of 'Piquin', Green pepper, 'Chilaca', 'Huacle'). 
identified; these alleles differentiated the chilis of southern and central Mexico from those of northern Mexico, likely due to the geographic distance and the morphological differences between the sweet peppers of Yucatán and those of the center and north of the country; these sweet peppers have a shape more similar to that of green peppers, with which it shares more alleles. In general, analyses of genetic diversity of the native chili populations of Mexico have revealed a very high degree of variability (Oyama et al., 2006; González-Jara et al., 2011; Pacheco-Olvera et al., 2012). All of this genetic diversity found in the native and wild chili populations of Mexico must be protected and conserved for future studies and for the identification of alleles of agronomic interest. This diversity is largely due to the fact that Mexico is the center of genetic diversity of the species C. annuum (Pickersgill, 2007), its high degree of cross-pollination (Djian-Caporalino et al., 2006) and the conservation and use of native species by Mexican farmers.

\section{Population genetic structure}

The data generated by the $\mathrm{F}$ statistics analysis are shown in Table 4. The values $F_{I S}$ (deviation of heterozygosity within each population) were negative, indicating a high number of heterozygotes within each population. The lowest values were found for the 'Mulato' hybrid (-0.497) and the green pepper variety (-0.462), while 'Guajillo' chili had -0.018 . In contrast, the positive data of $F_{I T}$ (differentiation among populations) indicate that there is a higher loss of heterozygotes. The green pepper variety and the 'Mulato' hybrid had a lower loss of heterozygotes than the mulatos and anchos. According to the $\mathrm{F}_{\mathrm{ST}}$ value (coefficient of general genetic differentiation), for the 'Mulato' chilis and sweet peppers there is wide genetic differentiation, $23 \%$, meaning that $77 \%$ of the observed variation is due to genetic variation among individuals within each population, and only $23 \%$ is due to variation among populations. In contrast, the group of 'Cristalino' chilis shows a moderate genetic differentiation: $85 \%$ of their genetic variation occurs among individuals within each population.

In ancho chilis, most of the genetic variation is found within each population, indicating that selection would be the best option for breeding in all of the populations, without neglecting the genetic variation found among populations of the groups of 'Mulato' chilis and sweet peppers in hybridization. This assertion is supported by data reported on native populations of Mexico, which reveal that genetic variation within each population is greater than among populations. For example, Pacheco-Olvera et al. (2012) reported $70 \%$ variation within populations of native chilis and $60 \%$ in wild chilis in northwestern Mexico. Contreras et al. (2011) found $86 \%$ variation within populations of 'Mulato' chili in Puebla. Oyama et al. (2006) also indicate that there is greater diversity within populations of domesticated and wild chilis of Mexico than among populations. In contrast, Albrecht et al. (2012), in a study with AFLP, found that the variation in $C$. baccatum L. of Central and South America is greater among accessions than within them. The existence of high polymorphism within each population of ancho chili is exhibited in the large number of fruit shapes, sizes and coloring, as well as diverse plant heights and diameters, making possible the establishment of genetic improvement procedures.

\section{Genetic relationships among populations}

According to the principal components (PC) analysis, 50.5\% of the variation was explained by the first eight PC (Table $5)$. Most of the alleles that are comprised in PC1 were determinant for separating the Yucatán population from the rest of the populations of this study since they are alleles that are generally only present in the populations of sweet peppers of this state: CM0005 C, Hpms 1-1 G, Hpms 1-1 I, Hpms 1-106 E, Hpms 1-6 I, and Hpms2-13 K. The other six alleles that had greater influence on this component are also found more frequently in sweet pepper populations and very infrequently in other populations. The allele Hmps $1-62 \mathrm{~F}$, which has a total frequency in the sweet peppers of Yucatán, is also found at intermediate frequency in populations of chilis from Durango and San Luis Potosí. Its frequency is very low or not found in the populations of Puebla, Zacatecas, and Guanajuato, while in the two hybrids (HM01 and HA01) it is absent.

The allele that contributed most to PC2 (Hpms 1-172 $K$ ) was found only in the 'Huacle', 'Piquin' and 'Chilaca' chili populations. These three populations are apparently very closely related genetically despite their morphological differences: 'Piquin' chilis are small, round and red when ripe, while 'Huacle' chilis have a trapezoidal shape and are black when ripe and the 'Chilaca' morphotype is brown when ripe and is long and thin (17 cm long $\times 2 \mathrm{~cm}$ wide). In a similar way, in PC3 the HpmsCASIG19 J allele is only present in the 'Piquin' and 'Chilaca' chili populations, while the allele Hpms 1-274 G is found only in the sweet peppers of Yucatán, and in 'Chilaca' and 'Piquin' chilis.

Table 4. Wright F statistics for five groups, four populations and three hybrids of chilis, based on 24 SSR loci.

\begin{tabular}{|c|c|c|c|c|c|c|c|}
\hline Chili type & $\mathrm{F}_{\mathrm{IS}}$ & $\mathrm{F}_{\text {IT }}$ & $\mathrm{F}_{\mathrm{ST}}$ & Chili type & $\mathrm{F}_{\text {IS }}$ & $\mathrm{F}_{\mathrm{IT}}$ & $\mathrm{F}_{\mathrm{ST}}$ \\
\hline 'Mulato' & -0.079 & 0.167 & 0.228 & 'Chilaca' & -0.222 & -0.222 & 0.000 \\
\hline 'Ancho' & -0.050 & 0.122 & 0.165 & 'Piquin' & -0.240 & -0.240 & 0.000 \\
\hline 'Cristalino' & -0.222 & -0.035 & 0.153 & 'Guajillo' & -0.018 & -0.018 & 0.000 \\
\hline 'Miahuateco' & -0.116 & 0.084 & 0.180 & Green pepper & -0.462 & -0.462 & 0.000 \\
\hline Sweet & -0.254 & 0.028 & 0.225 & Hybrid ('Ancho') & -0.237 & -0.237 & 0.000 \\
\hline 'Huacle' & -0.163 & -0.163 & 0.000 & Hybrid ('Mulato') & -0.497 & -0.497 & 0.000 \\
\hline
\end{tabular}

FIS: Deviation of heterozygosity within each population, $\mathrm{F}_{\mathrm{IT}}$ : differentiation among populations, F $\mathrm{F}_{\mathrm{ST}}$ : coefficient of general genetic differentiation. 
Table 5. First eight principal components, variation explained and alleles that have greatest influence on each component.

\begin{tabular}{|c|c|c|}
\hline $\begin{array}{l}\text { Principal } \\
\text { Component }\end{array}$ & $\begin{array}{c}\text { Variation } \\
\text { explained }(\%)\end{array}$ & Alleles that contribute most to each component \\
\hline 1 & 13.0 & $\begin{array}{l}\text { Hpms1-62 F, HpmsCASIG19 H, Hpms1-5 I, Hpms1-172 F, CM0005 C, Hpms1-1 G, Hpms1-1 H, Hpms1-1 I, Hpms2-2 F, } \\
\text { Hpms1-106 E, Hpms1-6 I and Hpms2-13 K }\end{array}$ \\
\hline 2 & 7.8 & Hpms1-172 A \\
\hline 3 & 7.0 & HpmsCASIG19 J and Hpms1-274 G \\
\hline 4 & 5.5 & $\begin{array}{l}\text { Hpms2-13 E, Hpms1-143 I, Hpms1-143 A, Hpms2-21 C, Hpms1-111 A, Hpms2-24 J, CMO005 E, Hpms1-5 L and } \\
\text { AF244121 C }\end{array}$ \\
\hline 5 & 5.2 & $\begin{array}{l}\text { Hpms1-62 G, AF244121 J, HpmsCASIG19 C, Hpms1-1 J, Hpms1-274 A, Hpms1-274 C, Hpms2-2 A, Hpms1-214 L, } \\
\text { Hpms2-21 A and Hpms1-173 D }\end{array}$ \\
\hline 6 & 4.7 & $\begin{array}{l}\text { CAN010950 D, Hpms1-173 A, Hpms2-21 E, Hpms2-24 G, Hpms2-24 A, Hpms1-6 C, Hpms1-214 K, Hpms2-2 B, } \\
\text { Hpms1-274 B, Hpms1-1 L, Hpms1-1 D, Hpms1-168 B, Hpms1-168 A, HpmsCASIG19 I and Hpms1-148 C }\end{array}$ \\
\hline 7 & 3.8 & Hpms1-5 K, Hpms1-172 J, Hpms1-111 H, Hpms1-111 I, Hpms1-143 D, Hpms1-173 C and Hpms2-13 B \\
\hline 8 & 3.5 & Hpms1-214 J, Hpms1-1 A, AF039662 B, AF039662 C, Hpms1-172 G, Hpms1-168 C, Hpms1-168 D and Hpms1-62 B \\
\hline
\end{tabular}

According to the dispersion of populations over the first two principal components (PC) shown in Figure 1, the populations of sweet peppers separate from the populations of north and central Mexico (Quadrant IV, Circle 4). The populations V-Pi ('Piquin') and O-Ch ('Chilaca') also form a differentiated group in Quadrant I (Circle 1). The hybrids $\mathrm{H}-\mathrm{Mu}$ ('Mulato') H-An (ancho) and H-Gr (green pepper), signaled with an arrow, are separated in Quadrant I and II. The populations of 'Mulato' and 'Miahuateco' from Puebla also make up a separate group in Quadrants I and II (Circle 2 ), while most of the chilis from the north of the country cluster in Quadrants III and IV (Circle 3). Although the first eight principal components explain just $50.5 \%$ of the total variation, analysis shows that there are genetic differences among the populations studied since the frequency of the alleles found for the loci allowed separation of the materials by the sites where they were collected: south, center, and north of Mexico. This differentiation in the ancho chilis showed that kinship is closer among populations of the same geographic location, largely attributable to the existence of exclusive alleles. The presence of these alleles is partly due to management and selection by farmers and plant breeders of each region as well as to the geographic distance between the materials. For this reason, genetic information has not been exchanged and distinct morphotypes have been preserved in each region. Diversification and genetic

Figure 1. Dispersion of native ancho chili populations of Mexico and controls, in function of the first two principal components.

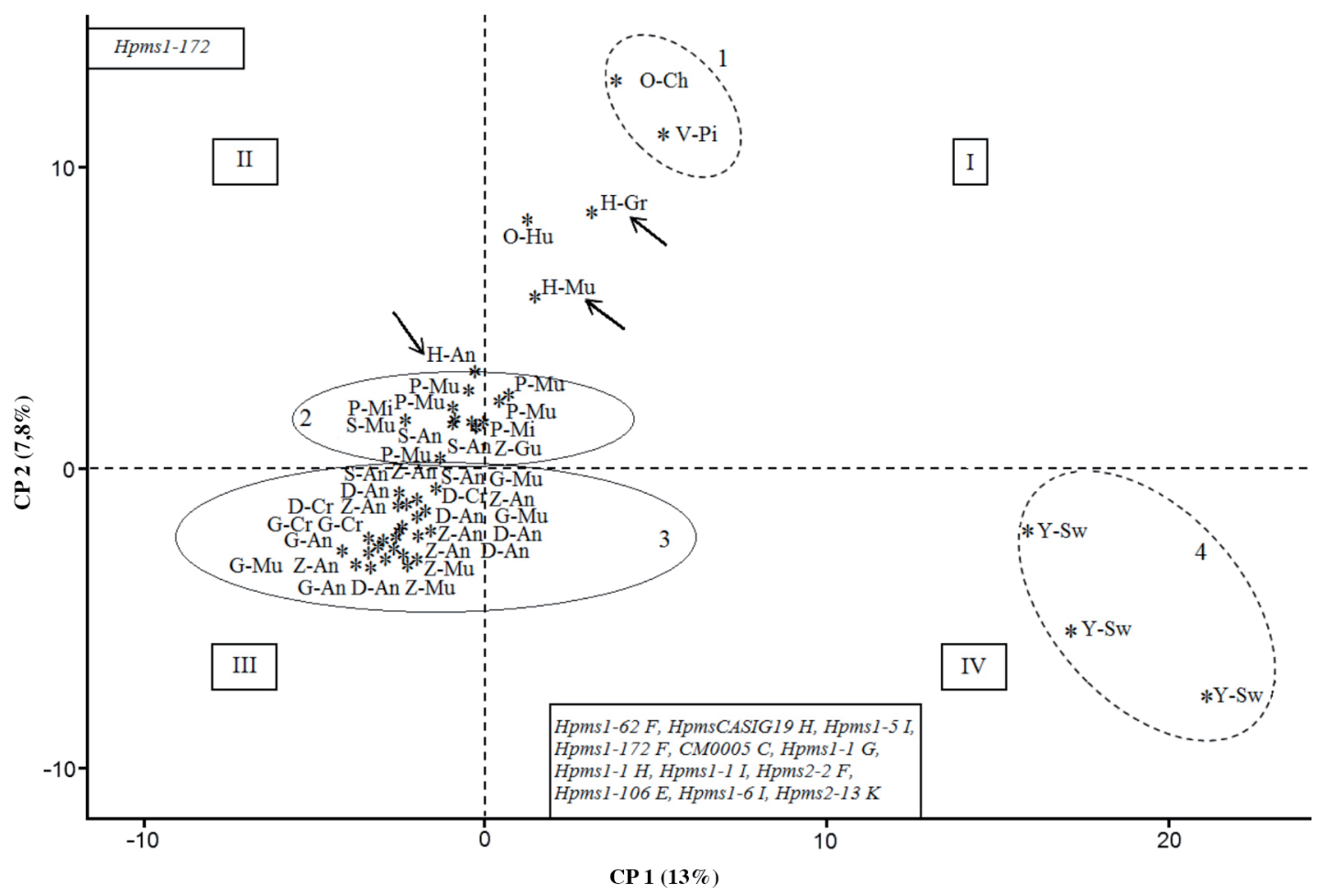

G: Guanajuato; Z: Zacatecas; S: San Luis Potosí; D: Durango; P: Puebla; O: Oaxaca; Y: Yucatán; V: Veracruz; H: hybrid; An: ancho; Mu: 'Mulato'; Cr: 'Cristalino'; Mi: 'Miahuateco'; Hu: 'Huacle'; Sw: 'Dulce'; Gu: 'Guajillo'; Ch: 'Chilaca'; Gr: Morron; Pi: 'Piquin'. 
variability of these populations offers an opportunity to deal with diverse plant health and environmental problems that arise during production of these chilis. It is also necessary to continue conserving the types of ancho chilis that express morphological and genetic characteristics unique to the region where they are grown.

The phylogram, based on Rogers genetic distance modified by Wright (1978), with VP01 as the external group and with the Neighbor joining clustering method, is shown in Figure 2. As in the results of PC analysis, the 'Chilaca' population (O-ch) is genetically very close to the 'Piquin' population (V-Pi), despite the large morphological differences: 'Piquin' chilis are round, very small and red when ripe, while the 'Chilaca's are long $(17 \times 2 \mathrm{~cm})$ and brown when ripe. The three populations of sweet peppers from Yucatán (Group III) were genetically very similar to the commercial hybrid green pepper (H-Gr). The chilis from the south (Group III) and center (Group II) clearly separate from the chilis collected in the north of Mexico (Group I), coinciding with the results of the principal components analysis. The chilis from northern Mexico are genetically more closely related, possibly due to the geographic proximity of the states where they were collected (Guanajuato, San Luis Potosí, Zacatecas, and Durango) and likely genetic flow among these populations. The hybrid chilis are placed more closely to the populations of San Luis Potosí (Group I-E). Despite the geographic distance between the two populations of
'Miahuateco' chilis, they were genetically very similar to the 'Guajillo' chili population (Group I-C), which in this case did not have exclusive alleles. It may be possible to achieve its differentiation with other SSR markers or with a larger number of populations.

The sweet peppers of Yucatán exhibit morphological differences in both their kidney shape and their size. Moreover, their growth, development and selection have taken place in an ecological niche very different from that of the other studied chilis; that is, they have had less contact with other sub-types of ancho chilis, and thus cross pollination has not occurred and their alleles have been conserved, making them genetically different. For the commercial green pepper type, whose origin and parents are unknown, their genetic proximity and the similarity of their alleles to those of sweet peppers of Yucatán, as well as their morphological likeness, is relevant. This study may provide a hint as to the origin of the green peppers in the market. However, more detailed studies with a larger number of populations will be needed to confirm this proposal. The commercial hybrids were also genetically closer to the populations of the north of the country, especially with the populations from San Luis Potosí, suggesting that these local materials, or other closely related, gave rise to these hybrids.

One 'Mulato' chili population of Guanajuato was that with the greatest evolutionary divergence, with a genetic distance of a little more than 0.55 , relative to the base position on the

Figure 2. Phylogram of 38 native populations of ancho chilis of Mexico and controls, using Rogers distance modified by Wright (1978) and the Neighbor joining clustering method.

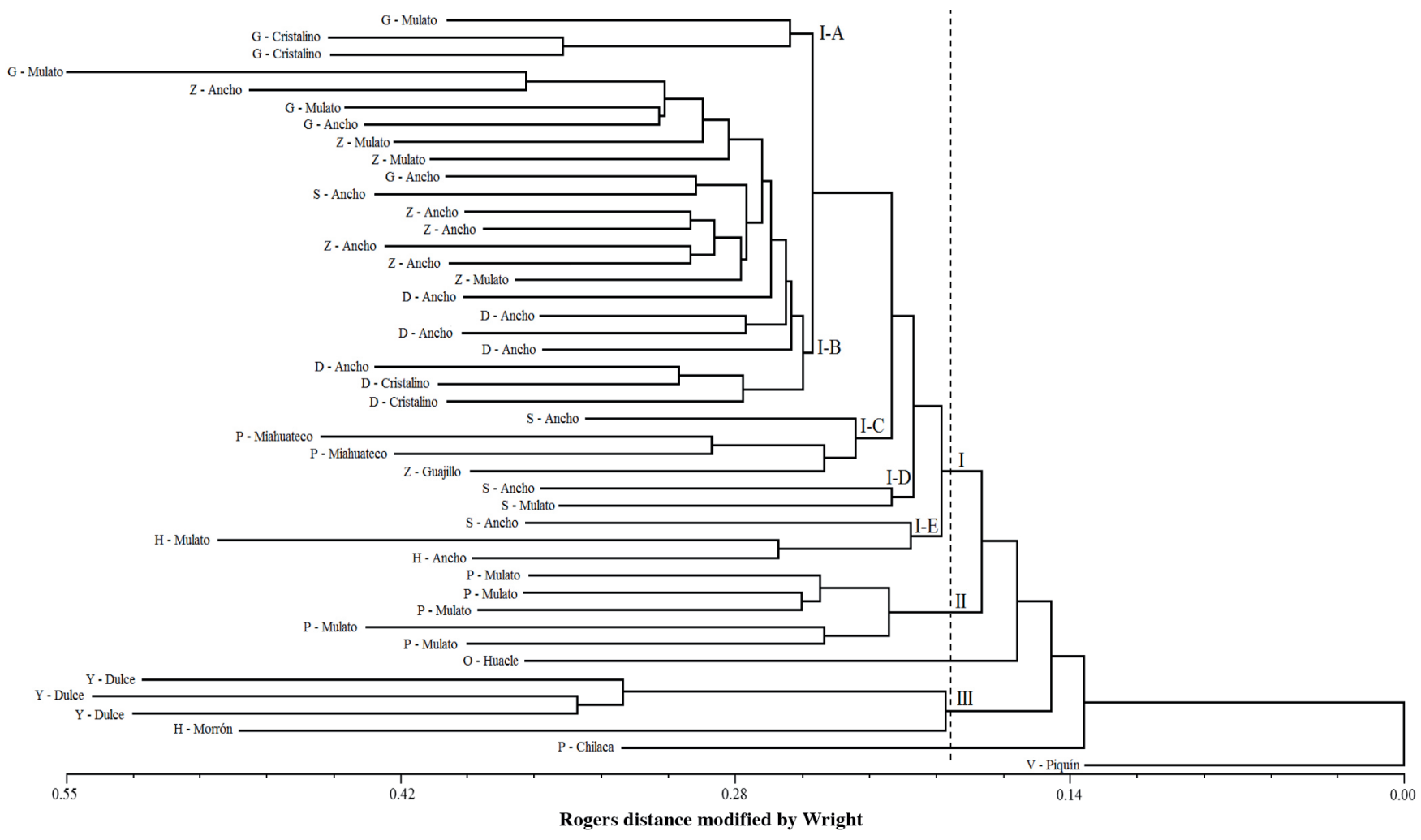

G: Guanajuato, Z: Zacatecas; S: San Luis Potosí; D: Durango; P: Puebla; O: Oaxaca; Y: Yucatán; V: Veracruz; H: hybrid. 
phylogram, followed by the populations of Yucatán sweet peppers and, immediately after, the commercial 'Mulato' chili and green pepper hybrids. The population of 'Piquin' chili (V-Pi) showed the least evolutionary divergence, followed by the 'Chilaca' population $(\mathrm{O}-\mathrm{Ch})$ with genetic distances of 0.14 and 0.34 , relative to the base position of the phylogram. In Mexico, there is a large quantity and diversity of 'Piquin' chilis (C. anпиum var. glabriusculum) found distributed throughout the country (Aguilar et al., 2010). In our study, 'Piquin' chili exhibits little genetic evolution, suggesting that 'Piquin' chilis, on the one hand, were preserved for some exclusive use and, on the other, underwent selection, giving rise to the different sub-types of the C. annuum that exist in Mexico, since among 'Piquin' chilis exists broad variation in shape, coloring, size, spiciness, aroma, and flavor.

\section{CONCLUSIONS}

The analysis of microsatellites indicates that there is broad genetic variability with a large number of heterozygotes in the native populations of ancho chilis of Mexico. This genetic variation is found in greater proportion within the populations than among populations. It is, thus, important to exploit this diversity through selection. The existence of exclusive alleles differentiated the populations by geographic origin; the populations formed groups that clustered populations collected in the south, center and north of Mexico. Therefore, closer kinship among populations is based on geographic location. Moreover, the presence of alleles common to all of the ancho chili populations and their checks indicates that they share a common genetic base. Also, the green pepper hybrid was genetically close to the sweet peppers of Yucatán and may thus suggest its origin. The commercial hybrids share more genetic similarities with populations of the north of the country, particularly with those populations from San Luis Potosí.

\section{REFERENCES}

Aguilar, R.V.H., T. Corona, P. López, L. Latournerie, M. Ramírez, H. Villalón, et al. 2010. Los chiles de México y su distribución. 114 p. Ed. SINAREFI. Colegio de Postgraduados, INIFAP, ITConkal, UANL, UAN, Montecillo, Texcoco, Estado de México, México.

Aguilar-Meléndez, A., P.L. Morrell, M.L. Roose, and S.C. Kim. 2009. Genetic diversity and structure in semiwild and domesticated chiles (Capsicum annuиm; Solanaceae) from México. American Journal of Botany 96:1190-1202.

Ahn, Y.K., S. Tripathi, J.H. Kim, Y.I. Cho, H.E. Lee, D.S. Kim, et al. 2014. Microsatellite marker information from high-throughput next-generation sequence data of Capsicum annuum varieties Mandarin and Blackcluster. Scientia Horticulturae 170:123-130.

Aktas, H., K. Abak, and S. Sensoy. 2009. Genetic diversity in some Turkish pepper (Capsicum annum L. var. annuum) genotypes revealed by AFLP analyses. African Journal of Biotechnology 8:4378-4386.
Albrecht, E., D. Zhang, R.A. Saftner, and J.R. Stommel. 2012. Genetic diversity and population structure of Capsicum baccatum genetic resources. Genetic Resources and Crop Evolution 59:517-538.

Applied Biosystems. 2005. GeneMapper Software Version 4.0. Reference and troubleshooting guide. Applied Biosystems, Foster City, California, USA.

Contreras, A.R., H. López, A. Santacruz, E. Valadez, V.H. Aguilar, T. Corona, et al. 2011. Diversidad genética en México de variedades nativas de chile 'Poblano' mediante microsatélites. Revista Fitotecnia Mexicana 34:225-232.

Djian-Caporalino, C., V. Lefebvre, A.M. Sage-Daubèze, and A. Palloix. 2006. Capsicum. p. 185-243. In Singh, R.J. (ed.) Genetic resources, chromosome engineering, and crop improvement. Volume 3. Vegetable crops. CRC Press, Boca Raton, Florida, USA.

Farooq, S., and F. Azam. 2002. Molecular markers in plant breeding-III: Practical applications and difficulties encountered. Pakistan Journal of Biological Sciences 5:1148-1154.

González-Jara, P., A. Moreno-Letelier, A. Fraile, D. Piñero, and F. García-Arenal.2011.Impact of human management on the genetic variation of wild pepper, Capsicum annuum var. glabriusculum PLoS One 6:e28715. doi:10.1371/journal.pone.0028715.

Hanáček, P., T. Vyhnánek, M. Rohrer, J. Cieslarová, and H. Stavělíková. 2009. DNA polymorphism in genetic resources of red pepper using microsatellite markers. HortScience 36:127-132.

Hernández-Verdugo, S., P. Dávila, y K. Oyama. 1999. Síntesis del conocimiento taxonómico, origen y domesticación del género Capsicum. Boletín de la Sociedad Botánica de México 64:65-84.

Ibiza, V.P., J. Blanca, J. Cañizares, and F. Nuez. 2012. Taxonomy and genetic diversity of domesticated Capsicum species in the Andean region. Genetic Resources and Crop Evolution 59:1077-1088.

Ince, A.G., M. Karaca, and A.N. Onus. 2010. Polymorphic microsatellite markers transferable across Capsicum species. Plant Molecular Biology Reporter 28:285-291.

Kwon, Y.S., J.M. Lee, G.B. Yi, S.I. Yi, K.M. Kim, E.H. Soh, et al. 2005. Use of SSR markers to complement tests of distinctiveness, uniformity, and stability (DUS) of pepper (Capsicum annum L. var. annuum) varieties. Molecules and Cells 19:428-435.

Laurentin, H. 2009. Data analysis for molecular characterization of plant genetic resources. Genetic Resources and Crop Evolution 56:277-292.

Lee, J.M., S.H. Nahm, Y.M. Kim, and B.D. Kim. 2004. Characterization and molecular genetic mapping of microsatellite loci in pepper. Theoretical and Applied Genetics 108:619-627.

Long, Y. 2009. Los senderos prehispánicos del Capsicum. p. 79105. In Long, J., and A. Attolini (coord.) Caminos y mercados de México. UNAM Instituto de Investigaciones Históricas, Instituto Nacional de Antropología e Historia, México.

Mimura, Y., T. Inoue, Y. Minamiyama, and N. Kubo. 2012. An SSR-based genetic map of pepper (Capsicum annum L. var. апnиum) serves as an anchor for the alignment of major pepper maps. Breeding Science 62:93-98.

Minamiyama, Y., M. Tsuro, and M. Hirai. 2006. An SSR-based linkage map of Capsicum annuum. Molecular Breeding 8:157-169.

Moses, M., P. Umaharan, and S. Dayanandan. 2014. Microsatellite based analysis of the genetic structure and diversity of Capsicum chinense in the Neotropics. Genetic Resources and Crop Evolution 61:741-755.

Nagy, I., A. Stágel, Z. Sasvári, M. Röder, and M. Ganal. 2007. Development, characterization, and transferability to other Solanaceae of microsatellite markers in pepper (Capsicum annum L. var. annuum) Genome 50:668-688. 
Nei, M. 1973. Analysis of gene diversity in subdivided populations. Proceedings of the National Academy of Sciences of the United States of America 70:3321-3323.

Nei, M., F. Tajima, and Y. Tateno. 1983. Accuracy of estimated phylogenetic trees from molecular data. II. Gene frequency data. Journal of Molecular Evolution 19:153-170.

Nicolaï, M., M. Cantet, V. Lefebvre, A.M. Sage-Palloix, and A. Palloix. 2013. Genotyping a large collection of pepper (Capsicum spp.) with SSR loci brings new evidence for the wild origin of cultivated $C$. annuum and the structuring of genetic diversity by human selection of cultivar types. Genetic Resources and Crop Evolution 60:2375-2390.

Oyama, K., S. Hernández-Verdugo, C. Sánchez, A. GonzálezRodríguez, P. Sánchez-Pena, J.A. Garzón-Tiznado, et al. 2006. Genetic structure of wild and domesticated populations of Capsicum annuum (Solanaceae) from Northwestern México analyzed by RAPDs. Genetic Resources and Crop Evolution 53:553-562.

Pacheco-Olvera, A., S. Hernández-Verdugo, V. Rocha-Ramírez, A. González-Rodríguez, and K. Oyama. 2012. Genetic diversity and structure of pepper (Capsicum annuum L.) from Northwestern Mexico analyzed by microsatellite markers. Crop Science 52:231-241

Pejic, I., P. Ajmone-Marsan, M. Morgante, V. Kozumplick, P. Castiglioni, G. Taramino, et al. 1998. Comparative analysis of genetic similarity among maize inbred lines detected by RFLPs, RAPDs, SSRs, and AFLPs. Theoretical and Applied Genetics 97:1248-1255.

Pickersgill, B. 1997. Genetic resources and breeding of Capsicum spp. Euphytica 96:129-133.

Pickersgill, B. 2007. Domestication of plants in the Americas: insights from Mendelian and molecular genetics. Annals of Botany 100:925-940.

Portis, E., I. Nagy, Z. Sasvári, A. Stágel, L. Barchi, and S. Lanteri. 2007. The design of Capsicum spp. SSR assays via analysis of in silico DNA sequence, and their potential utility for genetic mapping. Plant Science 172:640-648.

Rai, V.P., R. Kumar, S. Kumar, A. Rai, S. Kumar, M. Singh, et al. 2013. Genetic diversity in Capsicum germplasm based on microsatellite and random amplified microsatellite polymorphism markers. Physiology and Molecular Biology of Plants 19:575-586.

Rodrigues, K.F., and H.K. Tam. 2010. Molecular markers for Capsicum frutescens varieties cultivated in Borneo. Journal of Plant Breeding and Crop Science 6:165-167.

Rohlf, F.J. 2009. NTSYS pc: Numerical taxonomy system, Version 2.21c. Exeter Publishing, Setauket, New York, USA.

Sa, K.J., J.K. Park, K.J. Park, and J.K. Lee. 2010. Analysis of genetic diversity and relationships among waxy maize inbred lines in Korea using SSR markers. Genes \& Genomics 32:375-384
Saitou, N., and M. Nei. 1987. The neighbor-joining method: a new method for reconstructing phylogenetic trees. Molecular Biology and Evolution 4:406-425.

SIAP-SAGARPA. 2012. Agricultura producción anual. Servicio de Información Agroalimentaria y Pesquera (SIAP)- Secretaría de Agricultura, Ganadería, Desarrollo Rural, Pesca y Alimentación (SAGARPA), Ciudad de México, D.F., México. Available at http://www.siap.gob.mx/agricultura-produccion-anual/ (accessed 10 May 2014).

Stágel, A., I. Gyurján, Z. Sasvári, S. Lanteri, M. Ganal, and I. Nagy. 2009. Patterns of molecular evolution of microsatellite loci in pepper (Capsicum spp.) revealed by allele sequencing. Plant Systematics and Evolution 281:251-254.

Sugita, T., Y. Semi, H. Sawada, Y. Utoyama, Y. Hosomi, E. Yoshimoto, et al. 2013. Development of simple sequence repeat markers and construction of a high-density linkage map of Capsicum annuum. Molecular Breeding 31:909-920.

Varshney, R.K., A. Graner, and M.E. Sorrells. 2005. Genic microsatellite markers in plants: features and applications. Trends in Biotechnology 23:48-55.

Votava, E.J., G.P. Nabhan, and P.W. Bosland. 2002. Genetic diversity and similarity revealed via molecular analysis among and within an in situ population and ex situ accessions of chiltepín (Capsicum annuum var. glabriusculum). Conservation Genetics 3:123-129.

Warburton, M.L., G. Wilkes, S. Taba, A. Charcosset, C. Mir, F. Dumas, et al. 2011. Gene flow among different teosinte taxa and into the domesticated maize gene pool. Genetic Resources and Crop Evolution 58:1243-1261.

Wright, S. 1965. The interpretation of population structure by F-statistics with special regard to systems of mating. Evolution 19:395-420

Wright, S. 1978. Evolution and the genetics of populations. Vol. IV. Variability within and among natural populations. University of Chicago Press, Chicago, Illinois, USA.

Wu, F., N.T. Eannetta, Y. Xu, R. Durrett, M. Mazourek, M.M. Jahn, et al. 2009. A COSII genetic map of the pepper genome provides a detailed picture of synteny with tomato and new insights into recent chromosome evolution in the genus Capsicum. Theoretical and Applied Genetics 118:1279-1293.

Yeh, F.C., R. Yang, and T. Boyle. 1999. POPGENE Version 1.31. Microsoft Window-based freeware for population genetic analysis. Quick user guide. University of Alberta and Centre for International Forestry Research, Edmonton, Canada.

Yi, G., J.M. Lee, S. Lee, D. Choi, and B.D. Kim. 2006. Exploitation of pepper EST-SSRs and an SSR-based linkage map. Theoretical and Applied Genetics 114:113-130.

Yumnam, J.S., W. Tyagi, A. Pandey, N.T. Meetei, and M. Rai. 2012. Evaluation of genetic diversity of chilli landraces from North Eastern India based on morphology, SSR markers and the Pun1 locus. Plant Molecular Biology Reporter 30:1470-1479. 